\title{
Contribution of Voluntary Patriotic Practices on Poverty Reduction Initiatives in Zanzibar
}

\author{
Ayoub Mohammed Mahmoud* \\ Open University of Tanzania-Zanzibar Centre, Tanzania \\ *Corresponding author: Ayoub Mohammed Mahmoud, Open University of Tanzania-Zanzibar Centre, Tanzania
}

\begin{abstract}
The less known role of voluntary patriotic practices on poverty reduction in Zanzibar was a rationale for undertaking this study. This study aimed at assessing the actual contribution of voluntary patriotic practices on poverty reduction initiatives in Zanzibar, where West B District Council in Urban West Region, Zanzibar was used as a case-study. The research questions which guided the study included; firstly, what are the available voluntary patriotic practices in the West B District Council? secondly what are the impacts of voluntary patriotic practices on poverty reduction initiatives in West B District Council? and thirdly what are the factors affecting voluntary patriotic practices in West B District Council? The study applied case study method of cross-sectional research design. Various data collection methods including observation, interviews and questionnaire survey which were applied to sixty (60) respondents. The analysis of the collected qualitative and quantitative data was done through contents analysis and descriptive statistics respectively. Based on the analyzed data, the findings revealed the available voluntary patriotic practices in the West B District council including voluntary financial contribution $12(20 \%)$, voluntary material contribution $6(10 \%)$, voluntary manpower contribution $12(20 \%)$, voluntary service provision $7(12 \%)$, participatory community projects planning $4(7 \%)$, voluntary community support $5(8 \%)$, voluntary cleaning activities $4(7 \%)$, participatory security patrols $7(12 \%)$ and voluntary whistleblowing $3(5 \%)$. The revealed impacts of voluntary patriotic practices on poverty reduction initiatives in West B District Council namely saves costs $15(25 \%)$, avail development infrastructures $9(15 \%)$, enhance peace and social unity $7(12 \%)$, enhance social responsibility $6(10 \%)$, enhance social-infrastructure ownership 5(8\%), enhance transparency and impartiality 4(7\%), enhance community self-reliance $6(10 \%)$ and support government pro-poor initiatives $8(13 \%)$. The findings further revealed social factors, economic factors and institutional factors which influence the voluntary patriotic practices in reducing poverty in the study area. The study finally concludes the voluntary Financial contribution and voluntary Manpower contribution as the main voluntary patriotic practices available in reducing poverty in the study area. Also, the study further concludes that the impact of voluntary patriotic practices towards reducing poverty are mainly saving costs and supporting government pro-poor initiatives in the country. Finally, the study recommends many awareness creation programs to various actors; including government, CBOs and NGOs and community members on mainstreaming voluntary patriotic practices.
\end{abstract}

Keywords: Patriotism; Voluntary patriotic practices; Poverty reduction initiatives

\section{Introduction}

\section{Background Information of the Study}

According to the Advanced English Learner's Dictionary; patriotism is defined as affection and love a person has for his or her country and willingness to sacrifice for the betterment of it. The term patriotism is derived from the Latin noun pater meaning father. It further refers to a deep feeling of love for one's fatherland, a fundamental disposition for the common good. Patriotism is an emotional journey of loyalty, allegiance, impartial love and total obedience to one's country. Negedu [1] further defined patriotism as the set of good behaviors which show love, obedience and respect for one's country (For a person to be a patriot means to zealously love and support his or her country and its interests by any means. Patriotism is also perceived as a positive and supportive attitude to a 'fatherland' by individuals and groups [2]. Patriotism is very important since it makes a person loyal, obedient and supportive to his or her motherland, its people, leaders and the political system and works for its development. The patriotism implies individuals' 
level of attitudes and behaviors of being able to place the interests of the nation above their personal and group interests [1,2].

In many mixed views on patriotism, Ogwuonuonu [3] further posits patriotism as the love someone has for his or her own country and willingness to defend it in any given situation including being ready to defend the country against an enemy. On the other hand, many authors including Ihenyen [4] asserts that to be patriot to one's nation is not a duty or an obligation, it is a way of living, a way of dreaming and a way of dying for the future of the country. It is at this juncture that this very study underscores the need of unraveling the contribution of patriotism and its role for country's development where various voluntary patriotic practices have been taking place in various levels, ways and forms in many places in the world. Tanzania is one of the countries which encourage the use of community participation approach as a tool for tackling poverty. The community participation approach has been observed in many development strategies adopted in Tanzania over time. In 1964, Tanganyika united with Zanzibar and formed United Republic of Tanzania. Thereafter in 1967, Tanzania adopted African socialism and self- reliance policy mostly known as Ujamaa na Kujitegemea policy. This stimulated popular community participation through villagilization, small scale industry and agriculture intensification strategies where people could willingly volunteer working for the sake of their surrounding communities and nation at large [5].

In 1972 the government of Tanzania under the leadership President Julius K. Nyerere adopted the decentralization policy which aimed at increasing decentralization of power to the local people. However, the decentralization was reported to fail due to improper mechanisms of decentralization, low people's participation in poverty reduction programmes, various economic problems such as the oil crisis of 1973, the Kagera War between 1978 and 1979 and drought in 1974 which all altogether led to the decline of economic growth in the early 1980s [6]. Despite of all the deliberate initiatives which took place in different times, the prevalence of all forms of poverty is still high in Tanzania. According to the Household Budget Survey of 2007, the proportion of the population below the national food poverty line is $16.6 \%$ with slight decline from $18.7 \%$ in $2000 / 01$ and $21.6 \%$ in 1991/92 [7]. According to the same source of information, the population below the national basic need's poverty line is $33.6 \%$ and declined from $35.7 \%$ in $2000 / 01$ and $38.6 \%$ in $1991 / 92$. Poverty remains overwhelmingly high in rural areas where $87 \%$ of the poor population lives, and exceedingly majority (74\%) of poor Tanzanians are primarily dependent on agriculture. According to the Household Budget Survey of 2007 the proportion of the rural population below the national food poverty line is $18.4 \%$ and declined from $20.4 \%$ in $2000 / 01$ and $23.1 \%$ in $1991 / 92$, whereas the proportion of rural population below the basic need's poverty line is $37.6 \%$; it declined from $38.7 \%$ in $2000 / 01$ and to $40.8 \%$ in $1991 / 92$ [7].
On the other hand, the then Revolutionary Government of Zanzibar under the leadership of the President late Sheikh Abeid Aman Karume had successfully practiced numerous voluntary patriotic practices. The practices including building communal settlements, schools, hospitals and health centers in various areas of Zanzibar, were mainly done by voluntary mobilized workforce from the members of communities also voluntary material and financial contributions. According to MKUZA [8], The Revolutionary Government of Zanzibar (RGoZ) has consistently aspired to improve the welfare of her people mainly through increasing income, eradicating diseases and fighting ignorance as contained in the Vision 2020 and Millennium Development Goals (MDGs). In 2000, the Government adopted the Zanzibar Development Vision 2020. The Zanzibar Development Vision 2020 is a long-term development framework which charts out what Zanzibar aspires to be by the year 2020. The vision, outlines in broad terms, the economic, social and political aspirations of Zanzibar to guide future policies, strategies and plans. Furthermore, the RGoZ has committed itself to the pursuance and the attainment of the (MDGs) by the year 2015 in order to improve the wellbeing of the people of Zanzibar.

Poverty in Zanzibar as a whole and in both urban and rural areas is still a major problem that requires relentless efforts to be reduced or eliminated in any given time. The decline in the basic need's poverty over the period 2004/05-2009/10 is small and this holds for each of the strata and for the Zanzibar as a whole. Apparently, food poverty for the rural areas actually increased from 15.93 percent in 2004/05 to 16.76 percent in 2009 [8]. Most governments in developing countries seek solutions to eradicate poverty at international level, and this has resulted in developing and developed countries being signatories to the United Nations Millennium Development Goals (MDG) and Sustainable Development Goals currently. However, the results have been uneven across countries, with Africa having large populations still trapped in poverty [9]. On the other hand, the need of applying patriotic spirit of volunteering in various community mobilization programs for the sake of undertaking various economic activities has been quite significant and need to be highly incorporated in various development initiatives.

\section{Problem Statement and Study Objectives}

Despite the widely known challenges, usefulness and roles of voluntary patriotic practices towards nation building initiatives and community social and economic development activities [10-14], less remains to be known on the actual contribution of voluntary patriotic practices on poverty reduction initiatives in Zanzibar. According to UNDP [14] poverty reduction has been a common agenda for almost every government in the world such that many governments in developing countries including Zanzibar seek solutions to eradicate poverty at international level instead of strengthening their initiatives in their internal strength's capacities including the use of available people in the local levels. 
In the quest for an alternative development model that is inclusive, responsive, humanising, equitable and environmentally sustainable, a people-cantered development with high level of patriotic attitude and people's voluntary participation has been recognised as a new development paradigm today [11-14]. The Non-Governmental Organisations with their participatory approach, people's mobilising capacity, closeness to grass roots local communities and better insights into the needs of the people have emerged as alternative development model in the many areas of modern Zanzibar, particularly in Urban West region. The voluntary patriotic practices have highly evolved as a viable community development strategy. However, the organised voluntary patriotic practices in the field of community development and poverty reduction are comparatively new phenomenon, their contribution towards enhancing the existing poverty reduction initiatives remains less known hence the undertaking of this study was sought plausible.

It is a matter of fact that voluntarism spirit in the various areas of Zanzibar has gained momentum with the advancement of the society from time to time. However, in the current times, the role of voluntarism which is mostly pioneered by civil societies and some government structures; has been widely recognized as indispensable in the process of development $[10,14]$. The voluntary patriotic practices stand as an alternative development model which encourages greater people's participation from all levels hence being the best development model which is highly inclusive, humanizing, equitable and environmentally sustainable. The increasingly practiced voluntary patriotic practices stand as newly adopted paradigm of community development are envisaged as a the most effectives people-centered development with has been widely recognized as a new paradigm today socio-economic development $[2,8,14]$.

The roles and meanings of community-based participation in various socio-economic development activities in the Zanzibar settings have been recently introduced. In this regard, the concept of social capital is clarified as a core of community participation and further conceptualizes the meanings of community participation in the Zanzibar socio-economic development settings by introducing the concept of voluntary patriotic practices $[9,13]$. There have been some government authorities, civil societies and other voluntary groups which have mainstreamed the community participatory approach on various socio-economic development activities. The approach provides people's mobilizing capacity, closeness to grass roots and better insights into the needs of the people from local communities have emerged as alternative development agents in the poverty reduction spectrum. This among other things gives this study a rationale for revealing the contribution of voluntary patriotic practices on poverty reduction initiatives in Zanzibar, where West B District Council in Urban West Region, Zanzibar was used as a case-study. The study sought to address three specific objectives namely: a) To examine the available voluntary patriotic practices in the West B District Council.

b) To assess the impacts of voluntary patriotic practices on poverty reduction initiatives in West B District Council.

c) To examine the factors affecting voluntary patriotic practices in West B District Council.

\section{Research Methodology}

\section{Description of the Study Area}

The study was conducted at West B district, one of the districts found in Urban West Region, Unguja, Zanzibar. The selected district was sought suitable for the study since it is the place where various voluntary patriotic practices have been carried out recently including community mobilization for building schools' classrooms, library, laboratories and toilets. The area was easily accessible by a researcher due to limited time, cost for the data collection exercise. Furthermore, the area was suitable for obtaining data since it is easily accessible by the researcher hence accomplishing the data collection exercise on time. The study intends to take place in one randomly selected ward from West B District namely Kijitoupele ward. Two shehias were randomly sampled from the selected study ward to bring sampling units of analysis including community leaders, community members, school committee leaders, teachers and students from the study area.

\section{Study Design}

The study used a descriptive cross-sectional research design. According to Kombo and Tromp 2006, descriptive cross-sectional research design was envisaged to enable the researcher to collect data fast with regard to the shortage of time and resource available to be used in carrying out the study. This was useful to this study since the study uses a short period of time and based at a single case study namely Kijitoupele ward in West B District. The descriptive cross-sectional research design was advantageous since it allows the researcher to collect data only once per each respondent and go [15]. This design was used due to its various advantages such as cheapness in administering, quick to conduct maximization of respondent's participation as it was conducted only once. Under this design both qualitative and quantitative research data were generated and incorporated in the study to enrich the insight.

\section{Target Population}

The population for this study comprised of all residents, government and community leaders from West B District in Urban West region which is also widely known as Mjini Magharibi Region. The target population which comprised the study sampling frame including community leaders, community members, head-teachers, teachers, school committee leaders including Chairperson and Secretary as well as committee members from the selected shehias in the earmarked wards from West B district respectively. The 
mentioned population from these wards was regarded as good representative for drawing the thinking on the role of voluntary patriotic practices on poverty reduction initiatives in Zanzibar. Towards collecting useful information, the study involved the use of key informants. The key informants of this study were community development officers from West B district, elder citizens in the selected shehias and other government officials from the selected wards, including shehas, Councilors, Ward Education Officer and District Education Officer.

\section{Sample Size of the Study}

Best and Khan [16] define sample as a small proportion of population selected for observation and analysis. By observing of the characteristics of the sample one can make certain inferences about the characteristics of the population from which it is drowning. Miles and Huberman (1994) argue that a small size sample characterizes qualitative studies. The sample is sufficient to provide maximum in sight and understanding of the problem under study. The sample size determination formula for the present study is drawn from Bartleh et al. [17]. In this study the sample size was 60 respondents as shown in the Table 1 below. Under the selected shehias in the study area, the 60 randomly sampled respondents who represented the units of interest which were identified in the target population which were drawn from the two selected shehias respectively. The study sample size was envisaged to yield data and all variables of interest for the study. These respondents were selected randomly in order to get their views. Study used the sample size comprised of both male and female respondents, of who were picked from the randomly selected wards.

Table 1: Distribution of the number of respondents who participated in this study.

\begin{tabular}{|c|c|c|c|}
\hline \multirow{2}{*}{ Category of respondents } & \multicolumn{2}{|c|}{ Number of respondents } & \multirow{2}{*}{ Total } \\
\cline { 2 - 3 } & Male & Female & \\
\hline Community members & 20 & 20 & 40 \\
\hline Teacher & 6 & 6 & 12 \\
\hline School children & 10 & 10 & 20 \\
\hline Total & 30 & 30 & 60 \\
\hline
\end{tabular}

\section{Data Collection Techniques}

The study employed data collection techniques including questionnaires and interview in the process of collecting information from the study respondents. Questionnaires technique was used to gather data from all of 60 respondents namely community members, teachers and students from the selected two shehias of Kijitoupele ward. On the other hand, interview technique including key informants' interviews and focus group discussions were used for the key informants including community leaders Ward Education Officers, Community Development Officers and potential Educational Officers including head-teachers and school committee members in the study area. Both of qualitative and quantitative approaches were employed in this study for the purpose of having detailed information and ensuring triangulation and complementarily. The said combination was envisaged to increase the validity of results. Before actual data collection, research instruments which were also data collection tools were calibrated by pre-testing and pilot testing by using 10 randomly chosen people from the ward where actual data collection was to be conducted. The analysis of the tested instruments was done to improve the instruments' consistency, validity and reliability. Lastly the reviews on various literatures were made to supplement both collected primary and secondary data.

\section{Data Analysis Procedures}

Analysis of data used both quantitative and qualitative data analysis approaches including simple percentages, descriptive analysis and explanations to establish relationships of the variables employed in the study. Simple codification was employed to extract relationships and associations among the population variable. The simple qualitative classifications of data, distribution and the measures of dispersions were used in measure of the actual contribution of voluntary patriotic practices towards poverty reduction initiatives in Zanzibar.

\section{Results and Discussion}

\section{Socio-Economic Characteristics of Respondents}

Table 2: Socio-economic characteristics of respondents $(n=60)$.

\begin{tabular}{|c|c|c|}
\hline Characteristic & Frequency & Percent (\%) \\
\hline \multicolumn{3}{|c|}{ Sex of respondents } \\
\hline Males & 45 & 75 \\
\hline Females & 15 & 25 \\
\hline \multicolumn{3}{|c|}{ Age of respondents } \\
\hline $10-17$ years & 12 & 20 \\
\hline 18-29 years & 12 & 20 \\
\hline $30-49$ years & 30 & 50 \\
\hline $50-60$ years & 6 & 10 \\
\hline \multicolumn{3}{|c|}{ Education level of respondents } \\
\hline Secondary education & 11 & 18.3 \\
\hline Diploma Education & 24 & 40 \\
\hline Tertiary Education & 25 & 41.7 \\
\hline \multicolumn{3}{|c|}{ Experience in Participating in voluntary patriotic practices } \\
\hline $1-10$ years & 9 & 15 \\
\hline $11-20$ years & 15 & 25 \\
\hline $21-30$ years & 36 & 60 \\
\hline \multicolumn{3}{|c|}{ Positions held by respondents } \\
\hline Community members and leaders & 36 & 60 \\
\hline Education officers & 12 & 20 \\
\hline School children & 7 & 11.7 \\
\hline Parents & 5 & 8.3 \\
\hline
\end{tabular}


In the course understanding the key parameters involved in this study, an attempt of firstly shedding light on the relevant social-economic characteristics of the 60 study respondents who were involved in this study was carried out. The characteristics include age, sex, education, marital status and occupation as they are summarized and presented in Table 2 below. Respondents' characteristics were important in order to provide a snapshot on the background of the respondents and their suitability for this inquiry namely revealing the contribution of voluntary patriotic practices towards poverty reduction initiatives in Zanzibar.

The study findings showed that $75 \%$ and $25 \%$ of total number of study respondents in the study area were male and female respectively. The particular study finding is widely supported by Stiglitz [18], URT [13] and Adejumo [2] indicating that there are gender differences in adopting various community participation activities in the study area. On the other hand, the revealed education level of respondents, there was a clear understanding that the study respondents with low levels were the ones who used to work in the lower level including office attendants and vice versa. The study findings concur with what was reported by Njana [19] and UNDP [14] that higher level of education puts an individual in better understanding of existing real-life challenges including the challenges in the world of work, better decision-making ability to choose better alternative solutions to existing problems in the surrounding communities. Additionally, education may improve people's lives in such areas as health, civic participation, political interest and happiness of the prevailing community practices. However, the study findings are in line with the findings from Tanellari 2014 and Negedu [1] which further show that educated individuals are always participating more actively in helping in the community they live, including participating in voluntary patriotic practices which once they are well-organized, they tend to be more enjoyable.

In this study context the working experience was sought to be useful since it acts as an important factor which may result in different level of participation of the community members and organization workers in the course of participating in voluntary patriotic practices in the study area. The fact that majority of respondents (60\%) had worked and supported voluntary patriotic practices in the study area for more than 20 years the study findings imply that; the majority of respondents had high level experience in the subject matter of voluntary patriotic practices in the study area for many years. The fact that the study was centered on revealing the role of voluntary patriotic practices on poverty reduction initiatives in the study area as it studied different positions held by the respondents involved in the study. The participation of community members and leaders $36(60 \%)$, Education officers $12(20 \%)$, School children $7(11.7 \%)$ and Parents $5(8.3 \%)$ of all of the 60 respondents interviewed in the questionnaire survey shows an appropriate pool of respondents who could provide clear snapshot on the role of voluntary patriotic practices on poverty reduction initiatives in the study area.

This revealed study findings are in line with Stewart (2007) findings that sex, age, education levels, experience in participating in voluntary patriotic practices and positions held by respondents as the main socio-economic characteristics which strongly affect, and influence individuals and organization's cultural norms and the way people practice innovative practices. In the course of underscoring respondents' standpoint on the role of voluntary patriotic practices on poverty reduction initiatives in the study area community members and leaders were sought to be the potential respondents and their suitability for this inquiry due to wide understand of their experience of participating in voluntary patriotic practices in the study area. The presented socio-economic characteristics of the study respondents had a high influence and importance in the course of revealing the role of voluntary patriotic practices on poverty reduction initiatives in Zanzibar

\section{The Available Voluntary Patriotic Practices in the West B District Council}

Table 3: Factors affecting voluntary patriotic practices in West B District Council.

\begin{tabular}{|c|c|c|c|c|c|}
\hline \multirow{3}{*}{\multicolumn{2}{|c|}{$\begin{array}{l}\text { Factors affecting voluntary patriotic } \\
\text { practices }\end{array}$}} & \multicolumn{4}{|c|}{ Responses (\%) } \\
\hline & & \multicolumn{2}{|c|}{ YES } & \multicolumn{2}{|c|}{ NO } \\
\hline & & $\mathbf{n}$ & $\%$ & $\mathbf{n}$ & $\%$ \\
\hline \multirow{5}{*}{ Social factors } & Attitude & 50 & 83 & 10 & 17 \\
\hline & Preference & 45 & 75 & 15 & 25 \\
\hline & Relationships & 48 & 80 & 12 & 20 \\
\hline & Networking & 45 & 75 & 15 & 25 \\
\hline & Education level & 55 & 92 & 5 & 8 \\
\hline \multirow{5}{*}{ Economic factors } & Financial resources & 50 & 83 & 10 & 17 \\
\hline & Human resources & 46 & 77 & 14 & 23 \\
\hline & Infrastructures & 42 & 70 & 18 & 30 \\
\hline & Working Equipment & 35 & 58 & 25 & 42 \\
\hline & Legal Framework & 48 & 80 & 12 & 20 \\
\hline \multirow{2}{*}{$\begin{array}{l}\text { Institutional } \\
\text { factors }\end{array}$} & Policies & 45 & 75 & 15 & 25 \\
\hline & Training programs & 42 & 70 & 18 & 30 \\
\hline
\end{tabular}

The revealed available voluntary patriotic practices in the West B District Council presented in the Table 3 above include Voluntary financial contribution $12(20 \%)$, Voluntary material contribution 6(10\%), Voluntary manpower contribution $12(20 \%)$, Voluntary service provision $7(12 \%)$, Participatory community projects planning $4(7 \%)$, Voluntary community support $5(8 \%)$, Voluntary cleaning activities $4(7 \%)$, Participatory security patrols $7(12 \%)$ and Voluntary whistleblowing $3(5 \%)$. The revealed practices present the evidence on the effectiveness of communityled approaches to tackling poverty. Since Zanzibar has a strong 
history of community development and community-led activities in low income communities both in urban and rural from grassroots volunteering through to mutual exchange activities and the ownership of the members of the community towards community- driven socio-economic activities in the study area. From the study findings presented in the Figure 1 voluntary financial contribution and voluntary financial contribution were found as the one of highly applicable voluntary patriotic practices in the study area.

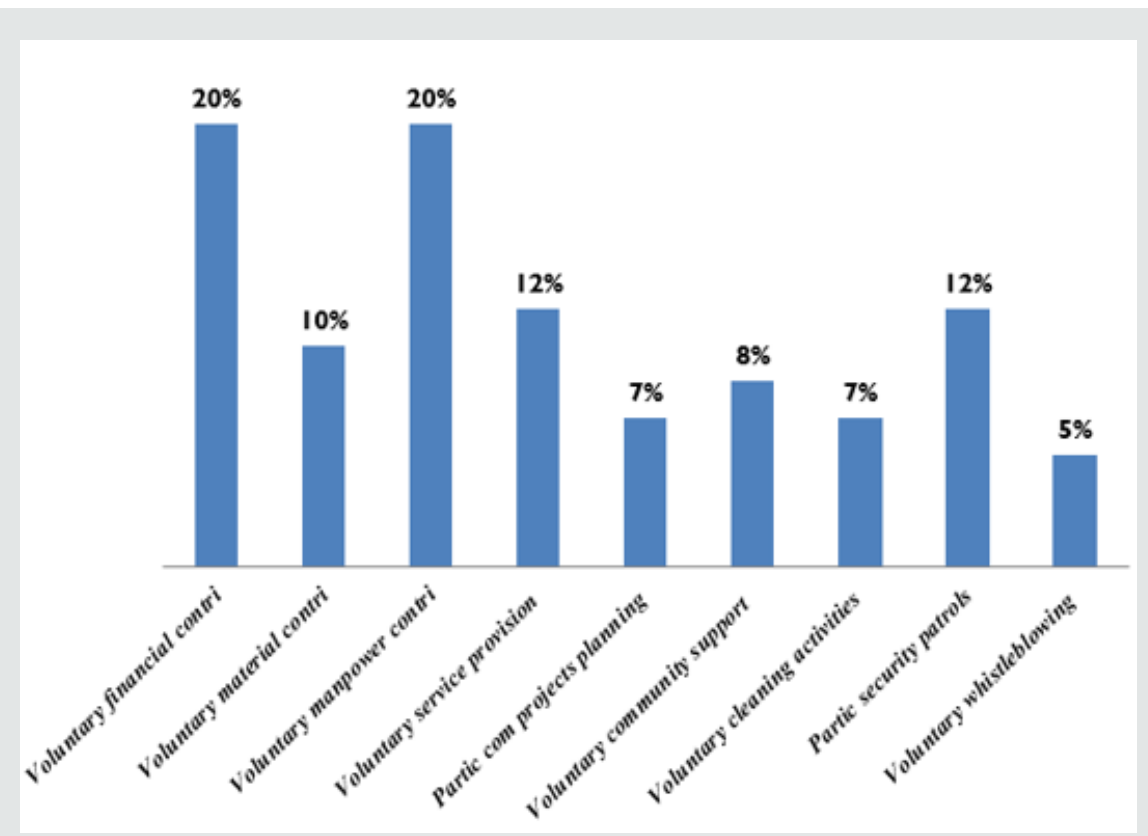

Figure 1: The available voluntary patriotic practices in the West B District Council.

From the study findings the leading voluntary financial contribution and voluntary financial contribution were found as the one of highly applicable voluntary patriotic practices in the study area as they were responded by $20 \%$ of the all respondents who were involved in this study. Following the revealed voluntary patriotic practices, the question of participation is important, as it is linked with the right to integration and citizenship. Participation implies the recognition of people as fully-fledged citizens and assumes they can substantially contribute to the development of society. Participation therefore implies respect and the recognition that people are competent in all aspects of personal and social life. This is true for all citizens.

According to ADB [20], most African countries including Zanzibar are faced with serious and worsening poverty. Given the magnitude of the problem, it is unrealistic for Governments in the region to be left alone to tackle this daunting task in light of the financial and institutional crises that is facing most of the countries in Sub-Saharan Africa. Therefore, to achieve sustainable development there is a need for more engaging more participatory and holistic approaches to dealing with the concerns of the poor in the region.

On the other hand, the concept of social capital is clarified as a core of community participation and further conceptualizes the meanings of community participation in the Zanzibar socioeconomic development settings by introducing the concept of voluntary patriotic $[13,14]$. The civil societies and other voluntary groups with their participatory approach, people's mobilizing capacity, closeness to grass roots and better insights into the needs of the people have emerged as alternative development agents in the poverty reduction spectrum. There is a range of civil society organisations whose participation is essential to address appropriately the challenge of poverty reduction. Private sector firms-large and small and both domestic and foreign non-governmental organisations (Plate 1), community-based organizations, have a role to play in promoting people's welfare which was traditionally expected from the state $[13,20]$.

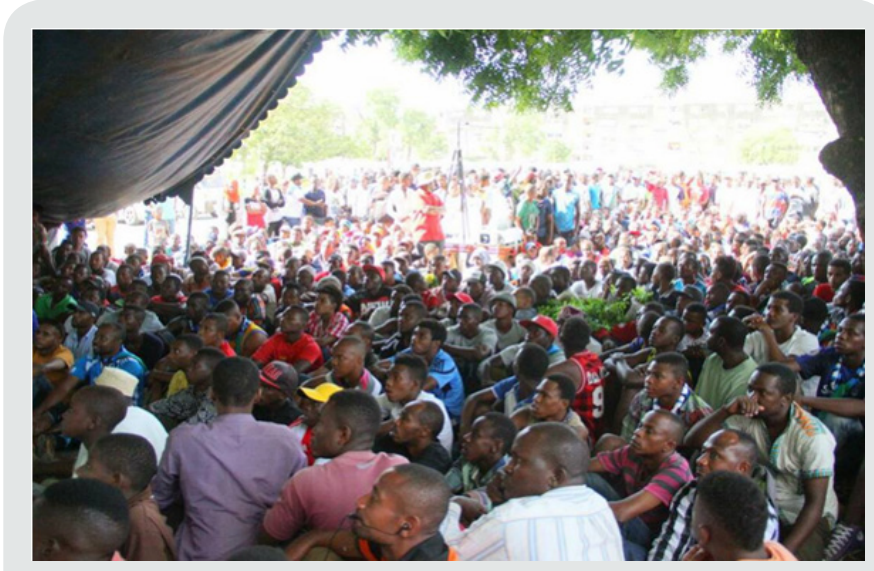

Plate 1: Participatory community mobilization practice in Kijitoupele ward - West B District.

Basing on the experiences and interpretations, it is the matter of fact that many studies of grassroots voluntary activity in low income communities identify important benefits that could impact on non-material forms of poverty by improving individual well- 
being, opportunities for social interaction and perceptions of area. There is less evidence that community-led forms of volunteering impact on material poverty. However, one study of a social group set up to tackle isolation among lone parent mothers found that improvements in well-being were also associated, in some cases, with movement into work or education. This implies voluntary action that aims to improve the non-material dimensions of poverty may also impact on 'pockets' or 'prospects. On-going support is essential to sustain volunteer commitment but may be a challenge in the current climate in low income areas due both to cuts in funding for support organisations and the tendency of residents to deprioritise community-based activities.

These practices were thought as the key drivers of effective community organising and social action include individuals with the right skills to lead campaigns, strong social networks, and appropriate levels of local voluntary and community sector support infrastructure. One important implication is that community organising may work less well in low income communities with the least developed voluntary and community sector infrastructure. This among other things was also revealed from one interview with a community member from the study area saying:

"We are always the reflection of our leaders. When our leaders direct and mobilize us we always come together and do the work together. This has been always taking place in form contributing money for development activities in our area including building schools and hospitals while sometimes we also go in the site and

\section{The Impacts of Voluntary Patriotic Practices on Poverty Reduction Initiatives in West B District Council}

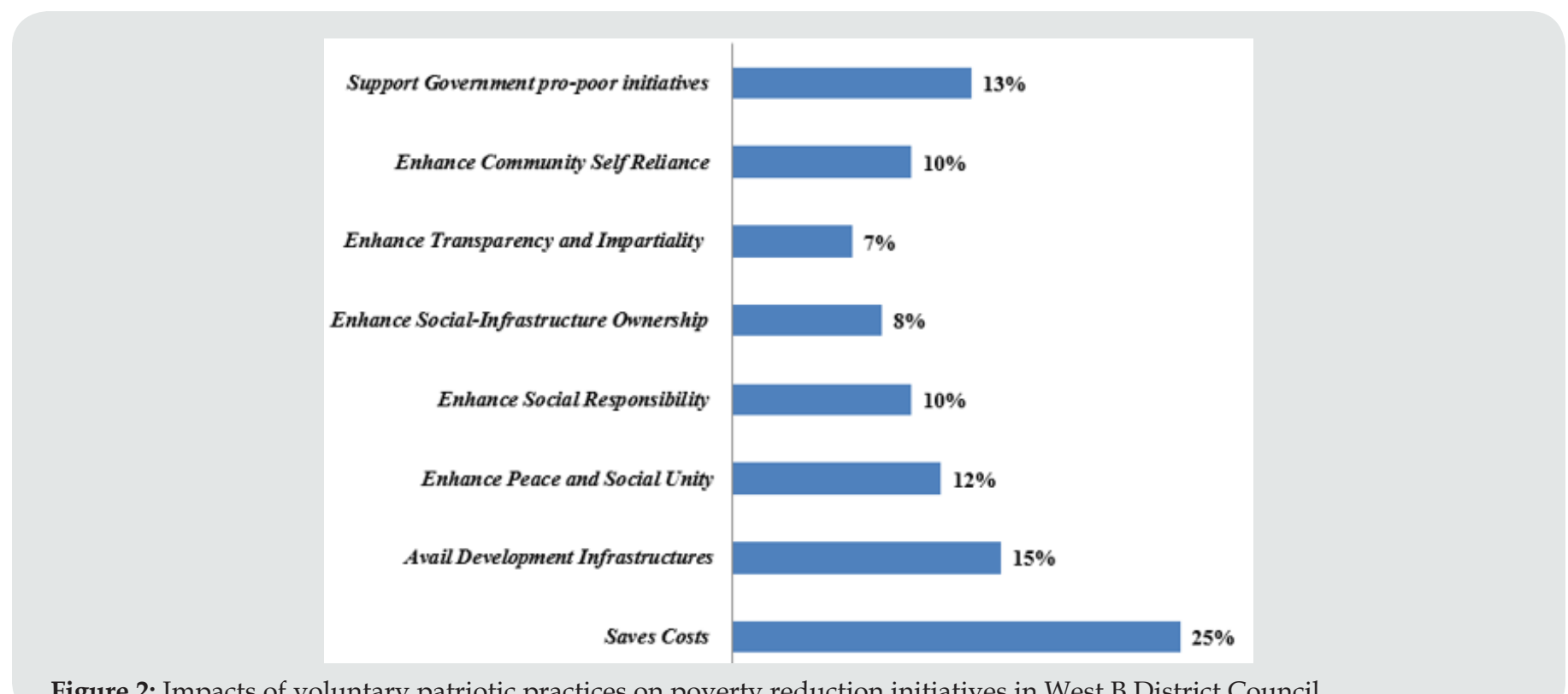

Figure 2: Impacts of voluntary patriotic practices on poverty reduction initiatives in West B District Council.

The study findings further sought to reveal the impacts of voluntary patriotic practices on poverty reduction initiatives in West B District Council. This was in line of the main thrust of the study such that the essence of voluntary patriotic practices participate in several construction operations to save costs. The spirit of volunteering in our area is very high since we have been seriously participating and directly seeing the changes. From the participation we have been rendering, we can quickly see our kids going to the nearby primary and secondary schools and recently the nearby health center facility has become into operation. Indeed, voluntary patriotic practices are quite useful to us as they provide us with social unity as well as the community facilities and tools for development".

On the other hand it can be learned from the study findings that the leading voluntary financial contribution and voluntary financial contribution in the responses of the study respondents were also found useful practices such as voluntary service provision $7(12 \%)$ and voluntary community support $5(8 \%)$ hence being one of highly applicable in the study area hence justifying the high level of community participation in the study area as they can be learned from the study area. Furthermore, from the study findings the leading voluntary financial contribution and voluntary financial contribution were found as the one of highly applicable voluntary patriotic practices in the study area as they were responded by $20 \%$ of the all respondents who were involved in this study. Community organising and social action approaches have significant potential to scale up and achieve wider change where linked into city-wide and national campaigns. Acquiring and managing community assets can improve outcomes related to material poverty by creating employment or supporting enterprise, whilst also enhancing nonmaterial experiences of poverty through better services, enhanced physical environment and improvements to community well-being. 
voluntary manpower contribution, voluntary service provision, participatory community projects planning, voluntary community support, voluntary cleaning activities, participatory security patrols and voluntary whistleblowing as discussed widely in the section 4.2 above stand as relevant evidence on the effectiveness of community-led approaches to tackling poverty in Zanzibar. The need of integrating community voluntary participation in the community development initiatives are a useful input in poverty reduction as they are revealed in the Figure 2 hereunder.

On the side of making citizens in the study area to voluntary participate in these revealed patriotic practices in the area while they are not paid for the service rendered, they are considered professionals and citizens as they often willingly participate in implementing voluntary patriotic practices. This could inform the actual role of voluntary patriotic practices play towards supporting poverty reduction initiatives in the study area. This system once mainstreamed in the society it reduces economic burden on government. According to Ross [21] the highly motivated community members provide both material and in-kind support towards improving social infrastructures and maintain high standards for professional and competent workforce [22]. The revealed impacts of the available patriotic practices include their usefulness towards justifying the effectiveness of communityled approaches to tackling poverty in Zanzibar. It is undoubtedly that the revealed patriotic practices in the study area have had a strong history of community development and community-led activities in low income communities both in urban and rural areas. The revealed impacts of voluntary patriotic practices result to community-driven socio-economic activities in the study area. Additionally, the successfully

practiced voluntary patriotic practices result to outcomes including improved community infrastructures including schools, hospitals and health centers in various areas of Zanzibar, hence improving socio-economic infrastructures. The revealed practices present the evidence on the effectiveness of community-led approaches to tackling poverty. Since Zanzibar has a strong history of community development and community-led activities in low income communities from both in urban and rural grassroots communities volunteering through to mutual exchange activities and the ownership of the members of the community towards community-driven socio-economic activities in the study area. The revealed impacts of voluntary patriotic practices on poverty reduction initiatives in West B District Council include saves costs 15(25\%), enhance socio-economic development infrastructures $9(15 \%)$, enhance peace and social unity $7(12 \%)$, enhance social responsibility $6(10 \%)$, enhance social-infrastructure ownership $5(8 \%)$, enhance transparency and impartiality 4(7\%), enhance community self-reliance $6(10 \%)$ and support government propoor initiatives $8(13 \%)$. The majority $15(25 \%)$ of respondents in the revealed study findings herein it was posited that voluntary patriotic practices saves costs in the course of improving development projects since they encourage people participation and manpower donation instead of overdependence on financial resources as it envisages voluntary manpower contribution.

On the other hand, the impacts of voluntary patriotic practices on poverty reduction initiatives stand mostly on the social capital contribution to the development process. This among other things fades away from the financial contribution and their measurements in the poverty alleviation initiatives. However, there are a number of reasons which support the use of monetary values in welfare measurement of poverty levels. Deaton [23], for example, argues that people tend to hide information about their income earnings during household surveys. On the other hand, people can willingly give information about products being consumed or produced in the household. Also, the prevalence of the informal sector in rural areas where farm and off-farm casual payments or wages are based on receipt in-kinds makes the task of collecting information on income difficult. In developing countries including Zanzibar the household incomes fluctuate more over the short term and are often reported less accurately in-line with findings from NBS [24] that it can be learned from the study findings that, voluntary patriotic practices save costs in the course of undertaking of development projects since they encourage use of manpower derived from community participation. From the findings presented in the Figure 2 , voluntary patriotic practices impact poverty reduction initiatives by saving costs and making possible use of the available manpower from the mobilized community initiatives. This was evident in the West B District Council where a lot of expenses have been saved such that by engaging communities in the development projects through voluntary patriotic practices. It is evident that the number of classrooms built, number of hospital wards built and cleaning operations in various areas hence voluntary patriotic practices practically and vividly witnessed in various areas.

On the other hand, the study findings revealed voluntary patriotic practices' impact by availing development infrastructures such that the mobilized community members have contributed by the shared mobilized workforce. This among other things makes the governments the ability to seek to adopt policies in the case of adopting voluntary patriotic practices in various development projects or in the expansion of present ones that contain explicit strategies for reinvesting portions of an enterprise's profit into the community. This can be done using a community development corporation that would seek to build positive relationships between a project and its community. Furthermore, study findings revealed voluntary patriotic practices impacting poverty reduction by supporting government pro-poor initiatives as it was responded by more than $13 \%$ of all respondents who participated in the study which concur findings from Negedu [1]. It is undoubtedly that the voluntary patriotic practices through engaging community mobilization have a great impact of supporting government propoor initiatives hence addressing directing poverty reduction initiatives in the study area. 
Factors Affecting Voluntary Patriotic Practices in West B District Council

In the course of addressing the fourth objective of this study, the study sought to reveal the factors affecting voluntary patriotic practices in West B District Council. After the thorough data analysis, the factors affecting voluntary patriotic practices in West B District Council are three-fold namely social, economic and institutional factors as presented in the Table 3 hereunder. The fact that major determinants of poverty are lack of income and purchasing power attributable to lack of productive employment and considerable underemployment, inadequacy of infrastructure, affecting the quality of life and employability etc. Factors affecting voluntary patriotic practices are cutting across engage some potential actors including NGOs which have a significant role in assisting the rural poor to break out of the vicious circle of poverty. A major source of the strength of NGOs comes from their idealism and values, which include a strong spirit of volunteerism and independence. Most NGOs consider empowerment of the poor as their major goal and objective. The empowerment can be as basic as enabling groups to improve their conditions through socio-economic development programmes or projects. This has not only economic benefits but also helps to ensure a unique visitor experience. Factors affecting voluntary patriotic practices in West B District Council are threefold namely social, economic and institutional factors are presented in the Table 3.

The findings presented in the Table 3 above reveal social factors such as attitude, preference, relationships, networking, education level being mentioned by $83 \%, 75 \%, 80 \%, 75 \%$ and $92 \%$ of the entire pool of respondents respectively. However economic factors which included financial resources, human resources, infrastructures were revealed by $77 \%, 70 \%$ and $58 \%$ while institutional factors which influence the voluntary patriotic practices in reducing poverty included Policies by $75 \%$ and Training programs $70 \%$ respectively. The research findings reflect real situation of voluntary patriotic practices in reducing poverty in different areas in Zanzibar such as in Urban West region indicated that $26 \%$ had never attended school, and a further $45 \%$ dropped out of school. In the context of voluntary patriotic practices in reducing poverty various factors have been cited to contribute to their efficiency of voluntary patriotic practices in Zanzibar. Despite of the initiatives there is still little networking between the agencies supporting the voluntary patriotic practices in reducing poverty. The voluntary sector, however, has been facing enormous structural, operational and financial constraints in their endeavor. While they have improvised ways and means to overcome certain set of constraints, they have encountered new ones in their endeavor, posing serious functional bottlenecks. Funding is one of the greatest constraints in voluntarism.

The voluntary patriotic practices in the transitional, poor agricultural society like the community in West B District with their fragment, dispersed nature on the one hand and rapid population pressure and increasing developmental challenges on the other, cannot any more bank upon for adequate support from the community or private philanthropy. They rely heavily upon institutional or government funding for their own survival and for successful implementation of development programmes. The magnitude of institutional funding from both the domestic as well as the foreign sources is indeed huge, running into thousands of Tshs. However, estimates of quantum of funding vary widely. On the other hand Rajan [25] argued that the alleviation of poverty, the upliftment and welfare of the neglected, oppressed, marginalised and the weaker sections of the society including the women, children, scheduled castes, scheduled tribes and the backward classes, landless laborer's, artisans, poor and marginal farmers etc., are the major concerns and the greatest challenge before the country today [26]. Factors affecting voluntary patriotic practices in West B District Council are so widely including the social, institutional and economic factors which included financial resources, human resources and infrastructures [27].

\section{Conclusion and Recommendations}

\section{Conclusion}

Basing on the revealed study findings, it is concluded that; the voluntary patriotic practices available in the West B District council include voluntary financial contribution 12(20\%), voluntary material contribution $6(10 \%)$, voluntary manpower contribution $12(20 \%)$, voluntary service provision $7(12 \%)$, participatory community projects planning $4(7 \%)$, voluntary community support 5(8\%), voluntary cleaning activities $4(7 \%)$, participatory security patrols $7(12 \%)$ and voluntary whistleblowing $3(5 \%)$. The study findings further concluded various impacts of voluntary patriotic practices on poverty reduction initiatives in study area namely saves costs $15(25 \%)$, avail development infrastructures $9(15 \%)$, enhance peace and social unity $7(12 \%)$, enhance social responsibility 6(10\%), enhance social-infrastructure ownership $5(8 \%)$, enhance transparency and impartiality 4(7\%), enhance community self-reliance $6(10 \%)$ and support government pro-poor initiatives $8(13 \%)$. The majority $15(25 \%)$ of respondents in the study findings posit that voluntary patriotic practices saves costs in the course of improving development [28]. The findings further revealed social factors such as attitude, preference, relationships, networking, education level being mentioned by $83 \%, 75 \%, 80 \%$, $75 \%$ and $92 \%$ of the entire pool of respondents respectively [29], however economic factors which included financial resources, human resources, infrastructures were revealed by $77 \%, 70 \%$ and 58\% while institutional factors which influence the voluntary patriotic practices in reducing poverty included Policies by $75 \%$ and training programs $70 \%$ respectively. The study further concludes the voluntary financial contribution and voluntary manpower contribution as the main voluntary patriotic practices in reducing poverty in the study area. 


\section{Recommendations}

Following the revealed study findings, it is hereby recommended to the following actors: The government is hereby recommended to introduce many awareness creation programs for raising awareness for mainstreaming voluntary patriotic practices in various development programs. On the other hand, CBOs and NGOs are hereby urged to incorporate various voluntary patriotic practices in all sorts of their operations. This includes conducting many awareness creation programs on the use voluntary patriotic practices in their project implementation. However, there should a deliberate move of making lobbying and advocacy on the use of voluntary patriotic practices to various levels of CBOs and NGOs operations since they are quite useful in workforce and resources mobilization. Additionally, community members are highly urged to enhance unity in improving them from time to time. The members are hereby recommended based to the revealed study findings to willingly and voluntarily continue mobilizing material and financial resources and manpower for enhancing development infrastructure in the study area.

\section{Acknowledgement}

Firstly, and foremost, I owe so much-and therefore am exceedingly grateful to my supervisor Dr. Venance Mutayoba and the entire academic staff of The Open University of Tanzania, Zanzibar Centre who supported my learning tirelessly. Indeed, their outstanding support rendered to me including academic guidance, advice, assistance, encouragement and constructive criticism throughout the preparation of this study and my entire master's degree program from The Open University of Tanzania. Secondly, I am highly indebted to all respondents who participated in this study. However, my utmost thanks and gratitude are due to the people of the Urban West Region in Zanzibar, indeed their cordial cooperation rendered to me in all sorts of my tenure of service has given me a lifetime lesson of volunteering tirelessly. Lastly but not the least my heartfelt gratitude is due to my lovely wife and our lovely children for their passion and endurance during the time of undertaking of this study.

\section{References}

1. Negedu I (2015) Nationalism in Nigeria: A Case for Patriotic Citizenship. American International Journal of Contemporary Research 5(3): 74.

2. Adejumo A (2014) Benjamin Adekunle Black Scorpion is Dead. Elombah, A Nigeria Perspective on the World Affairs.com.

3. Ogwuonuonu FE (2014) Why the Spirit of Patriotism is Low in Nigeria. National Network 9(17).

4. Ihenyen (2014) Patriotism. Golden Minds Nigeria.

5. Mtatifikolo F, Mabele, R (1999) Development Strategies and Poverty Reduction Initiatives. Analytical Discussion with Application to Tanzania. EASSRR 15(1).

6. Bagachwa MSD (1994) Poverty alleviation in Tanzania: recent research issues, Dar es Salaam University Press: Network for Research on Poverty Alleviation.

7. United Republic of Tanzania (2009) Annual Regional Economic Growth
Report. National Bureau of Statistics, Dar es Salaam, Tanzania, pp. 105.

8. MKUZA (2012) Zanzibar strategy for growth and reduction of poverty (ZSGRP II) The Revolutionary Government of Zanzibar.

9. World Bank (2000) World Development Report 2000/2001: Attacking Poverty. Washington, DC: World Bank, Oxford University Press, pp. 316.

10. Odhiambo NM (2009) Savings and Economic Growth in South Africa: A Multivariate Causality Test. Journal of Policy Modeling 31: 708-718.

11. Aikaeli J (2010) Determinants of Rural Income in Tanzania: An Empirical Approach' Research Report 10 /4, Dar es Salaam, REPOA

12. Simbila GK (2011) Challenges in Measuring Poverty in Tanzania., National Bureau of Statistics (Tanzania).

13. United Republic of Tanzania (2014) National Population Census 2012. National Bureau of Statistics, Ministry of Finance, Dar es Salaam, Tanzania. pp. 133.

14. United Nations Development Programme (2015) Human Development Report; Work for Human Development New York, USA.

15. Kothari C (2004) Research Methodology: Methods and Techniques. $2^{\text {nd }}$ (edn.). New Age International Limited Publishers, New Delhi, India. pp. 418.

16. Best JW, Kahn J (2006) Research in Education: New Delhi: Prentice Hall of India Pvt. Ltd.

17. Bartlett EJ, Kotrlick WJ, Haggins CC (2001) Organizational research: Determining appropriate sample size in survey research. Information Technology, Learning and Performance 19(10): 43-50.

18. Stiglitz J (1997) An agenda for development for the twenty-first century. $9^{\text {th }}$ Annual Bank Conference on Development Economics. World Bank, Washington DC, pp. 18.

19. Njana MA (2008) Arborescent species diversity and stocking in Miombo woodland of Urumwa Forest Reserve and their contribution to livelihoods, Tabora, Tanzania. MSc Dissertation, Sokoine University of Agriculture, Morogoro, Tanzania, pp. 214.

20. African Development Bank (2000) Tanzania: A poverty profile. Draft of Report No. 12298-TA. Population and Human Resources Division, Eastern Africa Development, Dar es Salaam. pp. 89.

21. Ross JA (1994) The impact of an in service to promote cooperative learning on the stability of teacher efficacy. Teaching and Teacher Education 10(4): 381-394.

22. Davis B, Winters P, Carletto G (2010) A Cross-Country Comparison of Rural Income Generating Activities. World Development 38(1): 48-63.

23. Deaton A (2004) The Analysis of Household Survey. A Micro-econometric Approach to Development Policy. John's Hopkins University Press. Baltimore and London. pp. 479.

24. National Bureau of Statistics (NBS) (2009) Household Budget Survey 2007. Final Report. Dar es Salaam, Tanzania, pp. 94.

25. Rajan RG (1994) Why Bank Credit Policies Fluctuate: A Theory and Some Evidence, The Quarterly Journal of Economics, Oxford University Press 109(2): 399-441.

26. Huberman AM, Miles MB (2000) Data management and analysis methods. In NK Denzin, YS Lincoln (Eds.). Handbook of Qualitative Research Thousand Oaks, CA: Sage Publications. pp. 428-444.

27. Kombo DK, Tromp DL (2006) Proposal and thesis writing: An introduction. Nairobi: Paulines Publications Africa.

28. Robert Becker Pickson, Koduah Dawud Enning, Anthony Siaw (2017) Savings-Growth Nexus in Ghana: Cointegration and Causal Relationship Analyses. TEL 7(2).

29. Weinberger K, Jutting JP (2001) Women's participation in local organizations: Conditions and constraints. World Development 29(8): 1391-1404. 
(c) (P)

This work is licensed under Creative Commons Attribution 4.0 License

To Submit Your Article Click Here:

Submit Article

DOI: 10.32474/CIACR.2018.05.000224

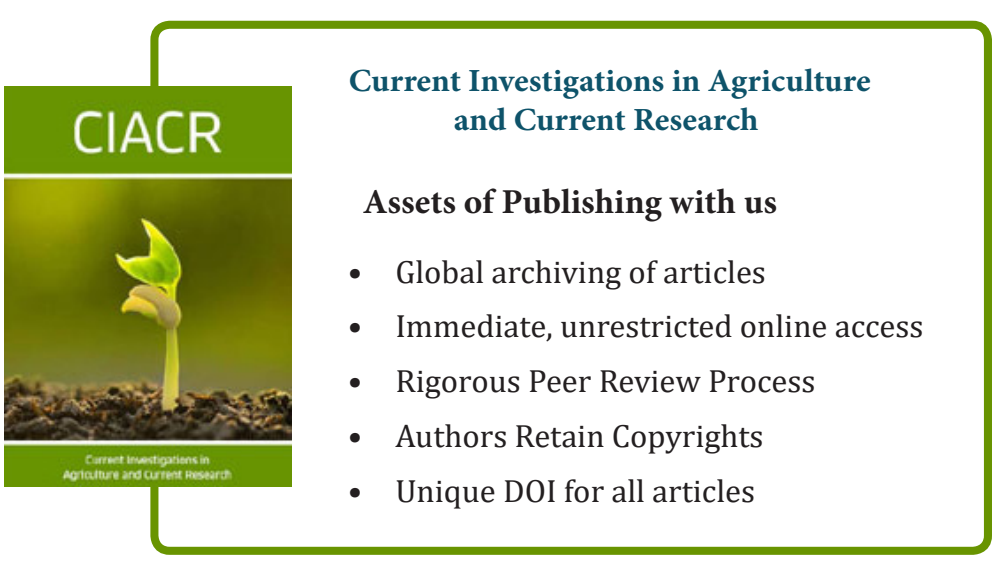

